\title{
Contracting for innovation in public services: Capabilities, institutions and intermediation
}

\author{
Kostas Selviaridis \& Martin Spring \\ Lancaster University Management School \\ LA1 4YX, Lancaster, United Kingdom \\ Email: k.selviaridis@lancaster.ac.uk; m.spring@lancaster.ac.uk
}

\begin{abstract}
Summary: This paper investigates how innovation intermediaries support UK public buying organisations and suppliers to contract for innovation. We find that intermediaries fill gaps in indirect capabilities related to innovation procurement and adoption by contributing expert knowledge, brokering connections and facilitating cooperation. Intermediaries also leverage their institutional capabilities and engage in institutional work to help shape an institutional environment that fosters public sector innovation. However, there is no conclusive evidence as to whether the deployment of intermediaries' institutional capabilities makes a difference in terms of the scale and rate of innovation procurement and adoption.
\end{abstract}

Keywords: contracting for innovation; indirect capabilities; institutional capabilities; innovation intermediaries

Submission category: Working paper

Acknowledgements: The authors gratefully acknowledge the financial support received by the British Academy of Humanities and Social Sciences and the Leverhulme Trust (Grant No.: SG161483).

\section{Introduction}

The aim of this paper is to investigate how innovation intermediaries support public buying organisations and suppliers to contract for innovation in the delivery of public services. Existing operations and supply chain management research on innovation sourcing is collectively concerned with how (large) firms leverage the resources and capabilities of their supply networks and integrate them with internal innovation strategies and knowledge to achieve superior innovation performance (Oke et al., 2013). Research on supplier involvement in NPD stresses the processes by which focal firms involve their suppliers in innovation activities (e.g. Lawson et al., 2015). Similarly, supply chain innovation literature examines how structural characteristics of supply networks and abilities of buyer (e.g. absorptive capacity) and supplier (e.g. innovativeness degree) influence innovation performance at the focal firm (Narasimhan and Narayanan, 2013; Bellamy et al., 2014).

The existing literature therefore stresses firm- and network-level characteristics and their impact on supply chain innovation processes. Despite their usefulness in explaining how focal firms draw on the capabilities of their suppliers to drive innovation performance, such research tends to assume that focal firms and their suppliers are largely capable of contracting for innovation. The extant literature also appears to underplay the institutional level of analysis in terms of how institutional forces (e.g. laws, regulations, routines and norms of conduct) influence the innovation process. This may be because in the private sector, the dominant empirical setting of innovation sourcing studies, the institutional set-up tends to be taken for granted as the context within which firms and supply chains operate.

Unlike innovation sourcing in the private sector, public buying organisations often encounter a shortfall of capabilities required to procure innovation (Edquist et al., 2015). 
Suppliers, especially small firms and innovative start-ups, also face limitations in their ability to contract with large public sector customers (Uyarra et al., 2014). In addition, in public sector settings, the institutional environment impacts significantly on innovation procurement and adoption practices (Rolfstam, 2013), and therefore capabilities related to managing institutional influences or shaping institutions conducive to innovation are relevant. Innovation intermediary organisations have a role in addressing some of these challenges by providing expertise and supporting innovation procurement and adoption processes (e.g. Kivimaa et al., 2019; Edler and Yeow, 2016).

In this paper, we synthesise capability and institutional perspectives to examine how innovation intermediaries fill in gaps in different types of capabilities required to effectively contract for innovation in public services settings. More specifically, we draw on indirect capabilities literature (Loasby, 1998) to analyse why and how public organisations and their (potential) suppliers draw on intermediaries' expertise to improve their ability to contract for innovation. We also employ the notion of institutional capabilities (e.g. Carney et al., 2016) to analyse how intermediaries may engage in institutional work by adapting or shaping institutions related to innovation procurement and adoption.

\section{Theoretical background}

This section develops the analytical framework of the study (Figure 1). In brief, we suggest that innovation intermediaries possess critical capabilities related to innovation procurement and adoption and to managing institutional influences. Intermediaries leverage these capabilities to support public buying organisations and their suppliers to contract for innovation.

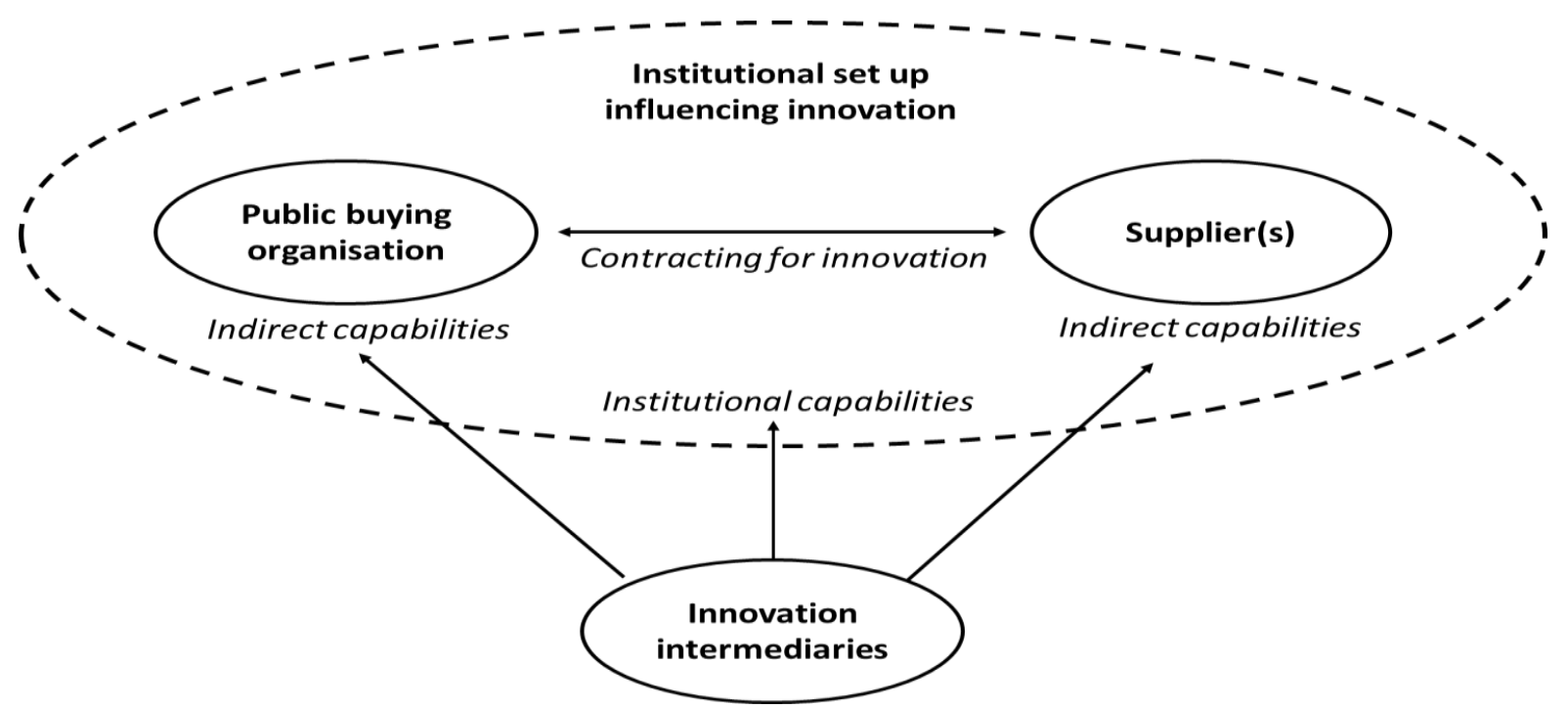

Figure 1: The analytical framework

\section{Innovation intermediaries}

Research on innovation intermediation, which originates in innovation management /policy studies, collectively strives to understand the role that intermediaries play in the innovation process (Howells, 2006). The existing literature suggests that innovation intermediaries can include both public /non-profit and private, for-profit organisations that operate across industries or focus on a certain sector. Intermediaries range from providers of knowledge intensive business services (KIBS) supporting the R\&D process, to research and technology organisations (RTOs), web-based platforms connecting supply and demand for innovation, and public institutes or government agencies with a specific remit e.g. health or energy innovation (e.g. Klerkx and Leeuwis, 2008a; Colombo et al., 2015). The latter type of intermediaries can 
be 'systemic' in that they help in setting agendas and influencing policy directions in fields of strategic importance such as sustainability (e.g. van Lente et al., 2003).

Overall, existing research seems to emphasise the multiple roles or functions that innovation intermediaries perform. By definition, innovation intermediation entails connecting and brokering interactions between buyers and suppliers of innovative solutions (Howells, 2006). Intermediaries help to fill in managerial, information and financial gaps of their clients (Klerkx and Leeuwis, 2008a). Managerial gaps addressed by intermediaries include definition of requirements or problems, selection of technological options, project management and solution adoption (Bessant and Rush, 1995). Intermediaries also provide critical information with respect to vision and strategic direction, demand articulation and knowledge possessed by relevant actors (Klerkx and Leeuwis, 2008b). Intermediaries can also facilitate access to finance for innovation activities; they can do that indirectly by increasing clarity around policy and regulatory frameworks and by educating private financers, and directly by providing grants, subsidies or funds for demonstration projects (Polzin et al., 2016). Innovation intermediaries can also help address cognitive gaps and reduce 'cognitive distance' between actors by serving as conduits for information exchange (Villani et al., 2017). Systemic intermediaries can have a key role in articulating needs and demands for innovative solutions, promoting certain technological options, aligning the incentives of network actors and coordinating their interactions and learning (Kivimaa, 2014).

Specifically in relation to innovation-oriented public procurement, Edler and Yeow (2016) found that intermediaries involved in health innovation processes contribute critical capabilities regarding identification of unmet needs, solution exploration, awareness raising within healthcare organisations, and innovation adoption. Intermediaries may also have a role to play in terms of long-term capacity and capability building within the public buying organisation (Edler and Yeow, 2016). However, several studies suggest that the impact of intermediaries depends on whether an intermediary is seen as impartial and neutral, and on its ability to continue operating unhindered by incoherent policy trajectories, institutional deficiencies and funding discontinuity (e.g. Klerkx and Leeuwis, 2008b). Overall, the above suggests that innovation intermediaries perform an important role in filling in capability gaps of their clients, from either the demand or the supply side. We now turn our attention to capabilities with particular emphasis on the notion of indirect capabilities.

\section{Direct and indirect capabilities}

A capability is "the reliable capacity to do something as a result of intended action. Capabilities fill the gap between intention and outcome, and they fill it in such a way that the outcome bears a definite resemblance to what was intended" (Dosi et al., 2000, p. 2). Capabilities are firstorder constructs reflecting the firm's ability to deploy resources (as zero-level constructs) to attain its goals (Wang and Ahmed, 2007). Capabilities also encapsulate routines in that they are often conceived as firm-level assemblages of lower-level routines that are developed and deployed to achieve specific outcomes (Salvato and Rerup, 2011; Dosi et al., 2000). The capabilities literature encompasses a set of distinct theoretical perspectives (e.g. resource-based view, knowledge-based view, routines and dynamic capabilities) and it is beyond the scope of this paper to provide a detailed review of all these approaches. Rather, the focus here is on 'indirect capabilities' and their distinction from 'direct' ones.

The pioneer of the notion of indirect capabilities is Loabsy (1998) whose seminal work drew a distinction between 'know what' and 'know how', with the latter referring not only to knowledge and skills but also to when and where these should be applied. Capabilities are constituted by 'know-how', both direct and indirect. Building on that premise, he also proposed a distinction between direct and indirect capabilities. Direct capabilities are equated with 'knowing how to do something' while indirect capabilities refer to 'knowing how to get 
something done by others' (Loasby, 1998). In other words, indirect capabilities refer to the know how required to get access to the capabilities and productive knowledge of other firms such as customers, suppliers and business partners (Spring and Araujo, 2014). Gaining and organising access to external capabilities is therefore a capability in itself (Araujo et al., 2003).

Firms are thus a set of direct and indirect capabilities (Loasby, 1998). Firms gain access to external capabilities through the market and through durable inter-firm relationships, which constitute a key mechanism to coordinate productive activities that are complementary, but are also based on dissimilar knowledge bases and competences (Richardson, 1972). In cases where such capabilities are not available in the market or are very costly to access, firms may decide to integrate forward or backwards to acquire such know how. Accessing complementary capabilities requires different types of indirect capabilities depending on whether the form of access can be described as market or relationship-based (Araujo et al., 2003). Concrete examples of indirect capabilities incorporate capacities into specifying and procuring a productive resource, capabilities to design and test purchased inputs as well as systems integration (Araujo et al., 2003). Spring and Araujo (2014) argue that indirect capabilities are crucial for a firm's ability to procure complex performance-based solutions. They identify six interrelated elements of indirect capabilities including contracting, boundary management practices, interface artefacts, IT infrastructure, valuing of others' capabilities and relating direct to indirect capabilities.

Indirect capabilities relate closely to the concept of 'contingent capabilities' (Flowers, 2004). Buying firms that procure complex, innovative solutions often 'know less than they buy' (Flowers, 2007) and thus seek external assistance from experts or consultants with respect to e.g. requirements definition, specification development, supply market research, contracting and solution implementation. The capabilities that external parties contribute are 'contingent' in that innovation relies upon their application (Flowers, 2004). Overall, this literature stream offers important insights into the types of capabilities focal organisations require to gain access to external resources and capabilities. It is less preoccupied though with the role of institutions in innovation processes and the capabilities related to managing institutional influences.

\section{Institutional capabilities}

Institutions are humanly devised constraints that shape and regulate interactions in the economy and society. They include formal (e.g. laws, regulations, property rights, and standards) and informal constraints such as culture, routines, norms, and practices (North, 1990). Institutions, as the 'rules of the game' or 'things that pattern behaviour', are directly relevant to innovation in that the latter results from cooperation and interactive learning among economic actors. While certain institutions (e.g., property rights laws) may enable innovation processes, others can play a hindering role given that institutional change is typically slower than technological change (Edquist and Johnson, 1997). The ability of organisations to manage interactions with the institutional set up (e.g. to adapt to or to change relevant institutions) is therefore a critical element of the innovation process (Edquist, 1997).

Capability and institutional perspectives are seen as compatible in that institutional environments influence the development of organisational routines and capabilities (Dunning, 2010). In turn, firms can leverage their resources and capabilities to shape the institutional environment. Specifically, the notion of institutional capabilities captures the ability of firms to cope with or actively manage institutional influences in a given operating context (Carney et al., 2016). Organisations engage in institutional work (Lawrence et al., 2011) and develop institutional capabilities to address institutional deficiencies. Institutional capabilities include the ability to establish close ties with institutional actors (e.g. government and politicians), to negotiate with them and honour credible commitments made, to adapt to existing institutional 
environments, and to change or create new institutions that enable the pursuit of profitable opportunities (Huang et al., 2017; Carney et al., 2016).

The concept of institutional capabilities originates in international business research examining how firms that internationalise their operations deal with institutional environments in host countries. It is, however, applicable to operations and supply chain phenomena. For instance, Wu and Jia (2018) show how multinational firms establishing supply chains in emerging economies work to engage with and influence local actors, adjust existing practices and norms of conduct, and actively change and shape beliefs and standards e.g. with regard to sustainability. Similarly, an analysis of institutional work and institutional capabilities is relevant to public sector settings where formal and informal institutions have a bearing on innovation procurement and adoption processes and outcomes (Rolfstam, 2013).

\section{Research method}

To develop an in-depth understanding of how innovation intermediaries support public buying organisations and their (potential) suppliers to contract for innovation, and any associated challenges, we employed a case-based research design (Voss et al., 2002). In particular, we conducted two in-depth case studies of innovation intermediaries operating in the UK defence and healthcare sectors, henceforth referred to as Alpha and Beta respectively. Alpha is an independent entity contracted by UK Ministry of Defence (MoD) to assist in the development and acquisition of innovative defence solutions. Beta is one of the 15 Academic Health Science Networks (AHSNs) set up as regional innovation agencies to spread innovation into the UK National Health Service (NHS). Table 1 provides background information about the two cases.

\section{Table 1: Overview of the cases}

\begin{tabular}{lll}
\hline & Alpha & Beta \\
\hline $\begin{array}{l}\text { Innovation } \\
\text { intermediary status }\end{array}$ & $\begin{array}{l}\text { Independent legal entity framed as } \\
\text { 'partnership' between MoD, industry and } \\
\text { academia. It operates based on } \\
\text { contractual relationship with the UK } \\
\text { MoD. }\end{array}$ & $\begin{array}{l}\text { One of the 15 AHSNs as autonomous bio- } \\
\text { enterprises funded by NHS England and the UK } \\
\text { Government Office for Life Sciences. They } \\
\text { operate based on 5-year licensing commitment } \\
\text { (investor-return relation with NHS England). }\end{array}$ \\
$\begin{array}{l}\text { User(s) of } \\
\text { intermediary's } \\
\text { services }\end{array}$ & $\begin{array}{l}\text { Several functions within the UK MoD } \\
\text { (primarily the armed forces and the } \\
\text { procurement and R\&D functions) }\end{array}$ & $\begin{array}{l}\text { (Potential) suppliers and NHS organisations } \\
\text { regionally /locally e.g. hospitals and clinical } \\
\text { commissioning groups }\end{array}$ \\
Operating model & $\begin{array}{l}\text { Project-based work (e.g. concept } \\
\text { demonstrators) triggered by MoD sponsor } \\
\text { request to solve specific problems. } \\
\text { Advice to users, including the MoD } \\
\text { procurement function. }\end{array}$ & $\begin{array}{l}\text { Identifying unmet needs and active scouting of } \\
\text { technological solutions; supporting SMEs to } \\
\text { develop and promote their innovations to the } \\
\text { NHS, and linking them to potential customers e.g. } \\
\text { hospitals. }\end{array}$ \\
\hline
\end{tabular}

Case selection followed a purposive sampling logic (Patton, 1990). First, defence and health are the two largest areas in terms of public procurement expenditure in the UK, but at the same time the rate and pace of innovation procurement and adoption within these sectors is low. In this context, intermediaries assume an important role in supporting buyers and /or suppliers and in accelerating innovation development and adoption. Second, our case selection considered which side (i.e. demand or supply) the intermediary supports. While Alpha is oriented towards aiding the UK MoD as the buying organisation, Beta mainly provides support to potential suppliers of the NHS. Beta also interfaces with the NHS and plays a role in identifying unmet needs and promising solutions, and in supporting innovation adoption and diffusion processes.

Data collection comprised 41 semi-structured interviews with managers within the two innovation intermediaries, relevant public buying organisations and (potential) suppliers. Interviews covered multiple themes such as the role of innovation intermediaries and the types 
of support provided to buyers /suppliers, the complementarity of capabilities provided by intermediaries in relation to the buyer's relevant capabilities, buyers' and suppliers' perceptions of the quality and impact of intermediaries' support, and broader challenges regarding innovation procurement and adoption in defence /healthcare. To complement and triangulate interview data, we analysed in excess of 50 documents and publicly available data e.g. policy reports and UK Government communications. We used the ATLAS.ti software to organise, analyse and code both primary and secondary data. We conducted both within- and cross-case analyses to identify patterns regarding the intermediaries' role and capability contributions.

\section{Findings}

This section presents the results of the within- and cross-case analyses. Table 2 summarises the main research findings with respect to the role played by the innovation intermediaries in the two case studies.

Table 2: Role and capability contribution of innovation intermediaries

\begin{tabular}{|c|c|c|}
\hline & Alpha & Beta \\
\hline $\begin{array}{l}\text { Intermediary } \\
\text { support to its } \\
\text { client(s) }\end{array}$ & $\begin{array}{l}\text { Alpha formulates and executes R\&D projects in } \\
\text { response to MoD sponsor request /question. The } \\
\text { project team delivers the 'solution' in a written } \\
\text { report and assists in implementation potentially. } \\
\text { 'Solution' informs / feeds into MoD procurement } \\
\text { processes }\end{array}$ & $\begin{array}{l}\text { Beta provides support to small firms } \\
\text { developing innovative products /technologies } \\
\text { of benefit to the NHS. Beta also fulfils a } \\
\text { technology horizon scanning function on } \\
\text { behalf of NHS, and has a role in influencing } \\
\text { NHS culture and behaviours in relation to } \\
\text { innovation }\end{array}$ \\
\hline $\begin{array}{l}\text { (Indirect) } \\
\text { Capabilities } \\
\text { accessed through } \\
\text { intermediary }\end{array}$ & $\begin{array}{l}\text { Evidence generation via experimentation and } \\
\text { concept demonstrator projects; solution de- } \\
\text { risking; requirements specification methods; } \\
\text { innovative contracting methods; brokering } \\
\text { connections between MoD and suppliers, and } \\
\text { between MoD functions. }\end{array}$ & $\begin{array}{l}\text { Identification and articulation of unmet needs } \\
\text { regionally; brokering connections between } \\
\text { SMEs and NHS; educating SMEs; supporting } \\
\text { SME funding applications; coordinating } \\
\text { clinical trials and evaluation studies; pre- } \\
\text { qualifying promising solutions }\end{array}$ \\
\hline \multirow[t]{3}{*}{$\begin{array}{l}\text { Institutional work } \\
\text { and capabilities of } \\
\text { the intermediary }\end{array}$} & $\begin{array}{l}\text { Establishing close ties with different functions } \\
\text { /stakeholders within MoD to try to influence } \\
\text { existing routines, practices and mind sets } \\
\text { regarding innovation procurement and adoption. } \\
\text { Creating a special-purpose property rights } \\
\text { arrangement to incentive supplier participation in } \\
\text { projects } \\
\text { Working with MoD stakeholders to adjust } \\
\text { /change standards and rules re: defence } \\
\text { acquisition e.g. agile procurement procedures, } \\
\text { new contract type conducive to ongoing } \\
\text { innovation /upgrades }\end{array}$ & $\begin{array}{l}\text { Engaging with UK Government departments, } \\
\text { policy makers and NHS agencies to inform } \\
\text { policies (e.g. Accelerated Access } \\
\text { Collaborative) and to influence policy } \\
\text { direction e.g. finance for health innovation } \\
\\
\text { Working with NHS Improvement to adjust } \\
\text { /change standards and models for hospital } \\
\text { reimbursement re: innovation adoption } \\
\text { (innovation tariffs) } \\
\text { Intervening to adjust regional /local } \\
\text { procurement standards to fit SMEs e.g. } \\
\text { participation in framework contracts }\end{array}$ \\
\hline & $\begin{array}{l}\text { Shaping localised norms of conduct e.g. } \\
\text { impartiality, transparency, deep engagement, } \\
\text { exploitation focus }\end{array}$ & $\begin{array}{l}\text { Helping to shape rules /regulations e.g. } \\
\text { dynamic procurement systems }\end{array}$ \\
\hline & $\begin{array}{l}\text { Working to influence senior MoD officials and } \\
\text { UK Government policy through publication of } \\
\text { 'white papers' and reports on defence innovation }\end{array}$ & $\begin{array}{l}\text { Influencing NHS staff mind sets, behaviours } \\
\text { and practices relevant to innovation adoption } \\
\text { and improvement }\end{array}$ \\
\hline
\end{tabular}

\section{Accessing indirect capabilities through innovation intermediaries}

The analysis focuses on how innovation intermediaries support public buying organisations and (potential) suppliers and what types of capabilities and sets of expertise they leverage to do so. A first key finding of the study is that the set of indirect capabilities required to contract for innovation in public service settings is distributed, rather than residing only within a single 
function (e.g. procurement) of a customer (public) organisation. Capabilities to procure and adopt /diffuse innovative products or technologies entail alignment, collaboration and interactive learning within the public buying organisation, and with suppliers, end users and other stakeholders. In this context, innovation intermediaries seem to play an important role in terms of brokering such interactions, creating workspaces for interactive learning and providing expert knowledge to public organisations and (small) suppliers.

The buying organisations (UK MoD and NHS) in the cases appear to face certain technical, managerial and cognitive gaps related to their ability to engage effectively with (potential) suppliers to source and adopt innovative solutions. Suppliers may also encounter similar gaps and challenges. This was particularly evident in the Beta case where small firms developing innovative products /technologies lack the resources, networks of contacts and knowledge and hence face limitations in terms of their ability to penetrate the NHS market. The innovation intermediaries studied fill in such capability gaps and provide critical know how and inputs e.g. with respect to needs identification, requirements specification, de-risking of innovative solutions through evidence generation and product validation, networking and brokering connection between buyers and suppliers, and implementation /adoption of innovations. In addition, intermediaries seem to contribute expert knowledge on innovation procurement. Alpha provides expertise in the design of innovative procurement processes and contracting methods that are more suitable to sourcing solutions (e.g. IT-related) that may require frequent upgrades or supplier-led innovation. Beta also seems to be involved in the development of 'agile' procurement methodologies that allow easier and faster access of SMEs with innovative products to NHS contracts.

Essentially, innovation intermediaries contribute certain elements of capabilities that buyers and /or suppliers require to contract for innovation. However, cross-case analysis uncovers a difference in terms of which organisation(s) the intermediary supports. Alpha, a partnership comprising the MoD as a unified customer, large and small defence suppliers, academic institutions and other specialist providers, focuses its effort on supporting the buying side (see also Table 1). Beta, on the other hand, appears to assume a bigger role in actively supporting capability development of (small) suppliers of innovation solutions that would potentially benefit the public healthcare system. It assumes a role in educating small firms, connecting them with hospitals and helping them to develop their commercial aptitude and their ability to navigate the highly complex NHS. In addition, Beta seems to provide inputs into the NHS's effort to source innovations by contributing to: a) definition and articulation of unmet needs at regional /local level, b) validation of innovative solutions that meet such needs, and c) adoption and spread of proven innovations in the NHS at regional and national level.

\section{Innovation intermediaries and institutional capabilities}

The empirical evidence suggests that institutional deficiencies prevalent in both UK defence and healthcare sectors typically slow down or even impede innovation procurement and adoption processes. More specifically, in the UK defence setting, relevant institutional challenges include rigid and complicated defence procurement rules and regulations, standardised procedures and practices (e.g. Scrutiny process), legacy systems and operating capabilities of armed forces being out of tune with innovative technologies, and legacy technical standards creating inter-operability issues. In a similar vein, the Beta case study uncovered several issues that hinder the ability of the NHS to source and adopt innovations. These include NHS structural (e.g. silo approach) and governance (e.g. distinction between commissioners and providers) aspects, incentive misalignments (e.g. provider reimbursement models) and cultural /behavioural barriers. In addition, the empirical study suggests a misalignment between the NHS procurement system and the efforts of other parts of the NHS to accelerate innovation development and adoption. In brief, NHS procurement units are incentivised to produce annual 
cost savings and to follow standardised supplier management and contracting practices that are not conducive to (small firm) innovation. The above institutional deficiencies or misalignments negatively influence the scale and rate of sourcing and adopting innovative technologies and solutions for the benefit of public sector customers.

Given the above institutional deficiencies, innovation intermediaries seem to perform institutional work and exercise their institutional capabilities in an attempt to shape an institutional environment that fosters innovation. Table 2 provides evidence from the two cases showing that Alpha and Beta actively engage and establish relationships with relevant actors to influence the institutional infrastructure relevant to innovation procurement and adoption. Interventions relate both to formal and informal institutions. For example, in the Alpha case the intermediary established a property rights regime that protects background IP of defence suppliers involved in collaborative $\mathrm{R} \& \mathrm{D}$ projects with competitor firms and the MoD as a customer. In addition, the Alpha partnership has established a code of conduct based on norms such as impartiality, neutrality, transparency, and deep engagement in projects that all participating firms must accept. In the Beta case, the intermediary puts significant effort (e.g. through organisation development initiatives and education programmes) into influencing and altering mind-sets and behaviours of clinicians and hospital managers in relation to innovation.

The findings suggest that innovation intermediaries engage in institutional work whose goal is to change existing rules and regulations related to procurement of innovative solutions, or even to shape new ones (Table 2). In the Alpha case, for example, the intermediary leverages its technical expertise and broader influence to lobby for the creation of agile procurement procedures and innovative contractual models that are more suitable for procuring fast-spin technologies and equipment that require periodic upgrades and innovation. In the Beta case, the studied intermediary uses its influence to adjust procurement-related standards to facilitate SME access e.g. minimum standards required for suppliers entering NHS framework contracts. The intermediary also engages in initiatives aiming to create new rules that facilitate SME access to the NHS market e.g. through the institutionalisation of 'dynamic procurement systems' in hospitals. A key observed element of the intermediaries' institutional competence in both cases is the establishment of close relationships with important actors and stakeholders, and the attempt to influence policy direction and implementation. Intermediaries do that in different ways e.g. through the publication of white papers on UK defence innovation by highly skilled senior managers of Alpha, and the participation of Beta's executives in implementation of flagship policy initiatives such as the Accelerated Access Collaborative. The latter's purpose is to provide an accelerate NHS adoption route to highly promising innovations.

\section{Discussion and conclusions}

The empirical findings suggest that innovation intermediaries have a significant role to play in the process of sourcing and adopting innovative solutions in public services settings. Innovation intermediaries contribute certain elements of indirect or 'contingent' capabilities (Loasby, 1998; Flowers, 2004) that buyers and /or suppliers require to contract for innovation. Innovation intermediaries also seem to perform institutional work and exercise their institutional capabilities (Carney et al., 2016; Lawrence et al., 2011) to help shape an institutional environment that fosters innovation. Institutional capabilities in this context refer to the ability to develop close ties with and influence UK Government Departments, policy makers and governmental agencies, and the ability to adjust or shape formal and informal institutions relevant to the innovation process. However, there is inconclusive evidence as to whether, and to what extent, these institutional capabilities exercised by innovation intermediaries actually make a difference given the significant institutional deficiencies outlined earlier. 
The study contributes to existing research on innovation sourcing in the following ways. First, it stresses the importance of indirect capabilities in relation to innovation procurement and adoption. Existing research underpinned by capability-based perspectives (e.g. Narasimhan and Narayanan, 2013; Oke et al., 2013) focuses on the focal firm's absorptive capacity and direct capabilities, and on how these relate to suppliers' direct capabilities, to drive innovation performance. It underplays, though, sets of capabilities required to gain access to suppliers' resources and capabilities, and to contract for innovation (Spring and Araujo, 2014). The empirical study has identified several elements of such indirect capabilities including the indirect know how that (small) innovative suppliers require to contract effectively with large public sector buyers. Second, we stress the role played by innovation intermediaries in filling gaps in the relevant indirect capabilities of their clients (buyers and /or suppliers). Intermediary organisations contribute critical sets of expertise and know how as part of the process of contracting for and adopting innovative products and technologies. Third, unlike much of the extant literature, we highlight the institutional processes underpinning innovation sourcing and the capabilities required to manage relevant institutional influences. In line with existing research on innovation intermediation (e.g. Kivimaa et al., 2019; Polzin et al., 2016), we find that innovation intermediaries develop close ties with important institutional actors and engage in institutional work to attempt to adjust existing formal and informal institutions or to shape new ones. To the extent that such intermediaries are perceived as independent and impartial actors, they may be better placed to perform such institutional work as compared to suppliers or even buyers. In addition, small suppliers (see Beta case) may lack connections and capacity for institutional work and hence rely on intermediaries' institutional capability.

The research presents policy implications regarding specific functions that innovation intermediaries can fulfill as 'educators' and as 'institutional engineers'. Regarding the former, intermediaries can potentially contribute to long-term capacity and capability building within public organisations and supplier firms. However, it is questionable whether the lessons learned through engaging with intermediaries actually stick within public buying organisations (especially large ones). Intermediaries can also play a critical role in terms of shaping an institutional environment fostering innovation procurement and adoption by public organisations. To be able to fulfil such a role, however, intermediaries may require significant support by governments in the form of formal mandates and regulatory powers, sustained finance and policy continuity and coherence.

The research has not explicitly focused on the impact of the intermediaries' support to buyers and /or suppliers. Further empirical research is required to analyse the performance effects of intermediaries' capability contribution e.g. in terms of contracts agreed, and the impact on the quality and cost efficiency of public services.

\section{References}

Araujo, L., Dubois, A., and Gadde, L.-E. 2003. The multiple boundaries of the firm. Journal of Management Studies, 40 (5), 1255-1277.

Bellamy, M., Gosh, S. and Hora, M. 2014. The influence of supply network structure on firm Innovation. Journal of Operations Management, 32, 357-373.

Bessant, J., Rush, H. 1995. Building bridges for innovation: the role of consultants in technology transfer. Research Policy 24, 97-114.

Carney, M., Dieleman, M. and Taussig, M. 2016. How are institutional capabilities transferred across borders? Journal of World Business, 51, 882-894.

Colombo, G., Dell'Era, C. and Frattini, F. 2015. Exploring the contribution of innovation intermediaries to the new product development (NPD) process: a typology and an empirical study. R\&D Management, 45 (2), $126-$ 146.

Dosi, G., Nelson, R.R. and Winter, S.G. 2000. Introduction: The nature and dynamics of organisational capabilities, In Dosi, G., Nelson, R.R. and Winter, S.G. (Eds), The Nature and Dynamics of Organisational Capabilites, Oxford: Oxford University Press, 1-18. 
Dunning, J. and Lundan, S. 2010. The institutional origins of dynamic capabilities in multinational enterprises. Industrial and Corporate Change, 19 (4), 1225-1246

Edler, J. and Yeow, J. 2016. Connecting demand and supply: The role of intermediation in public procurement of innovation, Research Policy, 45, 414-426.

Edquist, C. (Ed) 1997. Systems of Innovation: Technologies, Institutions and Organisations, Pinter, London.

Edquist, C. \& Johnson, B. 1997. Institutions and organisations in systems of innovation. Edquist, C. (Ed). Systems of Innovation: Technologies, Institutions and Organisations, Pinter, London 41-63.

Edquist, C., Vonortas, N.S and Zabala-Iturriagagoitia, J.M. 2015. Introduction: Public Procurement for Innovation, In: Edquist, C., Vonortas, N.S and Zabala-Iturriagagoitia, and Edler, J. (Eds.). Public Procurement for Innovation, Edward Elgar, Cheltenham, pp. 1-34.

Flowers, S. 2004. Contingent capabilities and the procurement of complex product systems. International Journal of Innovation Management, 8 (1), 1-20.

Flowers, S. 2007. Organizational capabilities and technology acquisition: Why firms know less than they buy. Industrial and Corporate Change, 16 (3), 317-346.

Howells, J. 2006. Intermediation and the role of intermediaries in innovation. Research Policy, 35, 715-728.

Huang, S., Ye, G., Zhou, J. and Jin, T. 2017. Institutional contexts, institutional capability and accelerated internationalization of entrepreneurial firms from emerging economies. Nankai Business Review International, $8(2), 231-262$.

Kivimaa, P., 2014. Government-affiliated intermediary organisations as actors in system level transitions. Research Policy, 43 (8), 1370-1380.

Kivimaa, P., Boon, W., Hyysalo, S. and Klerkx, L. 2019. Towards a typology of intermediaries in sustainability transitions: A systematic review and a research agenda, Research Policy, 48, 1062-1075.

Klerkx, L., Leeuwis, C., 2008a. Matching demand and supply in the agricultural knowledge infrastructure: experiences with innovation intermediaries. Food Policy 33, 260-276.

Klerkx, L., Leeuwis, C., 2008b. Balancing multiple interests: embedding innovation intermediation in the agricultural knowledge infrastructure. Technovation 28, 364-378.

Lawrence, T. B., Suddaby, R., and Leca, B. 2011. Institutional work: Refocusing institutional studies of organization. Journal of Management Inquiry, 20 (1), 52-58.

Lawson, B., Tyler, B., and Potter, A. 2015. Strategic suppliers' technical contributions to new product advantage: Substitution and configuration options. Journal of Product Innovation Management 32 (5), 760-776.

Loasby, B. J. 1998. The organisation of capabilities. Journal of Economic Behavior \& Organization, 35 (2), 139 160.

Narasimhan, R. \& Narayanan, S. 2013. Perspectives on supplier network-enabled Innovation, Journal of Supply Chain Management, 49 (4), 27-42.

North, D. 1990. Institutions, Institutional Change and Economic Performance (Political Economy of Institutions and Decisions), $2^{\text {nd }}$ ed., Cambridge University Press, Cambridge.

Oke, A., Prajogo, D. \& Jayaram, J. 2013. Strengthening the innovation chain: The role of internal innovation climate and strategic relationships with supply chain partners, Journal of Supply Chain Management, 49 (4), 43-58.

Patton, M.Q. 1990. Qualitative Evaluation and Research Methods, $2^{\text {nd }}$ ed., Sage, Newbury Park, CA.

Polzin, F., von Flotow, P., Klerkx, L., 2016. Addressing barriers to eco-innovation: exploring the finance mobilisation functions of institutional innovation intermediaries. Technological Forecasting \& Social Change, 103, 34-46.

Rolfstam, M. 2013. Public Procurement and Innovation: The Role of Institutions. Cheltenham: Edward Elgar.

Richardson, G. B. 1972. The organisation of industry, The Economic Journal, 82, 883-896.

Salvato, C. and Rerup, C. 2011. Beyond collective entities: multilevel research on organizational routines and capabilities. Journal of Management, 37, 468-490.

Spring, M. and Araujo, L. 2014. Indirect capabilities and complex performance: Implications for procurement and operations strategy, International Journal of Operations \& Production Management, 34 (2), 150-173.

Uyarra, E., Edler, J., Garcia-Estevez, J. Georghiou, L. and Yeow, J. 2014. Barriers to innovation through public procurement: A supplier perspective. Technovation, 34, pp. 631-645.

Van Lente, H., Hekkert, M., Smits, R., van Waveren, B., 2003. Roles of systemic intermediaries in transition processes. International Journal of Innovation Management, 7, 247-279.

Villani, E., Rasmussen, E. and Grimaldi, R. 2017. How intermediary organizations facilitate university - industry technology transfer: A proximity approach, Technological Forecasting \& Social Change, 114, 86-102.

Voss, C., Tsikriktsis, N. \& Frohlich, M. 2002. Case research in operations management. International Journal of Operations and Production Management, 22 (2), 195-219.

Wu, Z. and Jia, F. 2018. Toward a theory of supply chain fields - understanding the institutional process of supply chain localization. Journal of Operations Management, 58-59, 27-41. 